\title{
Towards a Spiritual Empire: the Christian Exegesis of the Universal Census at the Time of Jesus's Birth
}

Tiziana Faitini

in The Church and Empire. Cambridge University Press - Studies in Church History 54/2018, 16-30

https://www.cambridge.org/core/journals/studies-in-church-

history/volume/91D807DD82C9EFA4B2CA9BB786E70E48

\section{Introduction}

This paper analyses from a theologico-political perspective a selection of the ancient and medieval exegetical interpretations of Luke's description of the census carried out at the time of Jesus's birth (Luke 2:1-5). A clear understanding of this interpretative tradition, in fact, can best be gained by careful consideration of certain formal and juridical aspects of the Roman census (the so-called professio census, briefly described in \$2) upon which these authors elaborate ${ }^{1}$. On this ground, sections $\S 3$ and $\S 4$ provide a detailed illustration of the spiritualisation of the institution which led to the spiritual empire of Christ replacing the temporal empire of Augustus: the Roman census was Christianised and imbued with redemptive meaning by Christian exegetes, as has already been incidentally observed and is here in-depth argued ${ }^{2}$. Alongside this spiritualisation, however, from Orosius on, many commentators understood Jesus's participation in the census as a legitimation of believers's obedience to political authority; a political reading of Luke's pericope is shown to have been given, which can also be discerned in medieval political and juridical texts. The analysis thus provides us with a vivid example of the close, reciprocal intertwining of theological and juridical concepts and practices which has characterised the relationship between the Church and Empire since the former's foundation ${ }^{3}$.

\footnotetext{
${ }^{1}$ On the profound, theological and juridical, influence of this institution, see Tiziana Faitini, The Latin Roots of the 'Profession'. Metamorphoses of the Concept in Law and Theology from Ancient Rome to the Middle Ages, History of Political Thought (forthcoming in 2017). Suffice it to mention that this explains the reason why the act which sanctions the beginning of the life within a religious order has been defined religious profession.

${ }^{2}$ See Ilona Opelt, 'Augustustheologie und Augustustypologie', Jahrbuch für Antike und Christentum, 4(1961), 44-57, at 46, who referred to a 'Christianisierung des Römischen Census', quickly mentioning Origen, Ambrose, Orosius and Gregory the Great.

${ }^{3}$ For an introduction to the extensive bibliography on political theology, and the historical intertwining of theology and politics, see Henning Ottmann, 'Politische Theologie als Begriffsgeschichte', in Volker Gerhardt, ed., Der Begriff der Politik, Bedingungen und Gründe politischen Handelns (Stuttgart, 1990), 169-88; Michele Nicoletti and Luigi Sartori, Teologia politica (Bologna, 1991); Robert Hepp, 'Theologie, politische', in Joachim Ritter, ed., Historisches Wörterbuch der Philosophie, 13 vols (Basel, 1998), 10: 1105-1112; Christian Meier, 'Was ist politische Theologie?',
} 


\title{
2. The professio census and its presence in Luke's Gospel
}

The biblical reference to the universal census, or registration, ordered by Cesar Augustus and held at the time of Christ's birth, is extremely well known. The first lines of the second chapter of Luke's Gospel read as follows:

\begin{abstract}
And it came to pass, that in those days there went out a decree from Caesar Augustus, that the whole world should be enrolled (ut describeretur universus orbis). This enrolling (descriptio) was first made by Cyrinus, the governor of Syria. And all went to be enrolled (ut profiterentur), every one into their own city. And Joseph also went up from Galilee, out of the city of Nazareth into Judea, to the city of David, which is called Bethlehem: because he was of the house and family of David. He went to be enrolled (ut profiteretur) with Mary his espoused wife, who was expecting a child ${ }^{4}$.
\end{abstract}

In this passage, the words describo/descriptio and profiteor are all used to translate the Greek apographesthai/apographé, which was a technical term rendering the Latin censum profiteri or professio census, i.e. the Roman law institution of the census ${ }^{5}$.

According to tradition, the census was introduced in Rome by Servius Tullius in the sixth century BC. Held regularly during the Roman Republic, it consisted in an official declaration by the pater familias of his family and property, made on oath, roughly every five years, before designated officials. The procedure was assigned to the magistracy of the censores from the middle of the fifth century. Their task was to count all citizens and divide them, according to their rank and wealth, into the various classes of the Centuriate order. From the end of following century, the process involved identifying citizens as members of a particular tribe, which replaced both the curiae and family membership in the definition of citizenship. This designation served as the framework for

in Jan Assmann, ed., Politische Theologie zwischen Ägypten und Israel (München, 1995), 3-18; Peter Scott and William T. Cavanaugh, eds, The Blackwell Companion to Political Theology (Malden Mass., 2004).

${ }^{4}$ Luke 2: 1-5 (Douay-Rheims version, Baltimore, 1899, slightly modified). For the Vulgate of Jerome the Biblia Sacra iuxta Vulgatam versionem, ed. Robert Weber and Roger Gryson (Stuttgart, 2007), is used. There are a number of problems with the historical identification of the census spoken of by Luke; see, for useful references, Paul W. Barnett, 'Apographe and apographestai in Luke 2, 1-5', Expository times, 85 (1973-74), 377-80.

${ }^{5}$ For the Greek text, see Novum Testamentum Graece, ed. Eberhard Nestle, Kurt Aland et al. (Stuttgart, 2012). In the New Testament the Greek term also appears in Acts 5:37, which speaks of the prophet Judah the Galilean and emphasises that he was born during the census, probably referring to the one mentioned by Luke, and in Heb 12:23, which the Vulgate translates as 'ecclesiam primitivorum qui conscripti sunt in caelis'. Apographesthai/apographé generally mean "to enter in a list/list or register", and are often referred to the declaration of property or persons liable to taxation, and to the Roman census in particular. On the use of these terms in the New Testament and in early Christian literature, see F. Blass, A. Debrunner, A Greek Grammar of the New Testament and Other Early Christian Literature, ET Robert W. Funk (Chicago-London, 1961), §5.3, 5; the entries 'apographé/apographomai' in A Patristic Greek Lexicon, ed. Geoffrey W.H. Lampe (Oxford, 1976), 190; and the remarks made by Joseph A. Fitzmyer in The Gospel according to Luke, ed. Joseph A. Fitzmyer, The Anchor Bible 28-28A (New York, 1981), vol. I, 405, further elaborating on the technical, fiscal, meaning of apographé. 
the collection of taxes, for military conscription, and for eligibility to vote in the assembly of the comitia tributa ${ }^{6}$.

As scholars have clarified, the census focussed on the valuing of property but, as a consequence, was also crucial to the institute of citizenship, and thus key to the political, military and fiscal organisation of the Roman res publica ${ }^{7}$. The act of declaration made in front of censors implies admission within a political, military and fiscal order: the definition of each person's civic and social identity, and their holding of citizenship, was contingent upon this act. Moreover, the census was associated with the so-called regimen morum, ensuring that citizens behaved in accordance with their dignitas, and ended in a purification ceremony (lustrum). This served as a ritual refounding of the city, attesting to the fact that citizen rolls did not include anyone unworthy and so providing the city with divine protection ${ }^{8}$.

\section{The exegetical tradition: from Origen to Bede}

The lengthy exegetical elaboration on Luke's pericope, to which we will now turn, sheds light on what may be called a theological translation of a specific, juridical, institution, and, from a general point of view, on the intertwining between theological and juridical conceptualisations ${ }^{9}$.

The first note-worthy explanation of this passage is written by Origen of Alexandria in his Homilies on Luke, and has survived only in Jerome's translation. In earlier Christian texts, with the partial exception of Hippolytus of Rome ${ }^{10}$, the census ordered by Augustus is mentioned to give historical,

\footnotetext{
${ }^{6}$ See Elio Lo Cascio, 'Il census a Roma e la sua evoluzione dall'età «serviane» alla prima età imperiale', Mélanges de l'École française de Rome 113/2(2001), 565-603. With important modifications, the census was to last throughout the imperial era, as attested by article 50.15 (De censibus) of the Digesta and by some provisions collected in the Codex Iustiniani (e.g. C. 4.47.3 and C. 8.53.7-8) On the tasks of the censores, see Michel Humm, 'I fondamenti della Repubblica romana: istituzioni, diritto, religione', in Alessandro Barbero, ed., Storia d'Europa e del Mediterraneo, 15 vols (Roma, 2008), 5: 467-520, at 489-91.

${ }^{7}$ See Michel Humm, 'Il regimen morum dei censori e le identità dei cittadini', in Alessandro Corbino, Michel Humbert and Giovanni Negri, ed., Homo, caput, persona. La costruzione giuridica dell'identità nell'esperienza romana (Pavia, 2010), 283-314, at 311-12.

${ }^{8}$ See Humm, 'I fondamenti della Repubblica romana', 491.

${ }^{9}$ To contextualise my analysis in a broader historical perspective, see the monographic issue of Politica e religione. Annuario di teologia politica/Yearbook of political theology: Censo, ceto, professione. Il censimento come problema teologico-politico (2015), and Tiziana Faitini, Il lavoro come professione. Una storia della professionalità tra etica e politica (Roma, 2016).

${ }^{10}$ In his Commentary on Daniel (IV, 9, 2-3), Hippolytus contrasts the Roman empire and the heavenly kingdom, thus giving the census a significantly different interpretation from the tradition I outline. He observes that when the Romans flourished, Jesus, through the apostles, summoned all nations and made a nation of Christians with a new name in heart. His kingdom 'is counterfeited by that which rules according to the operation of Satan, but similarly this kingdom also collects those born from all nations and prepares those who are called Romans for war. And on account of this also the first census happened under Augustus [...] so that the men of this world, being registered in the earthly kingdom, were called Romans, but those who believe in the heavenly kingdom were named Christians' (ET Thomas C. Schmidt, 2010, at $125-26$, online

at
} 
objective, evidence of the time and the place of Jesus' nativity ${ }^{11}$, but Origen elaborates upon Luke's passage, working out its spiritual meaning. He defines the first universal census as a sacrament (sacramentum) - and here we should remember that this word indicated the military oath taken by men enlisting as soldiers in Rome ${ }^{12}$. He then observes that Christ would necessarily have been 'recorded in the census of the whole world (in totius orbis professione)', so that 'he could enrol those from the whole world "in the book of the living" with himself': only this fact makes it possible for believers to see their very names inscribed in the book of the living, of which the Book of Revelation speaks ${ }^{13}$. An implicit parallel is drawn between the census and the last judgement, which will become a topos, from Gregory the Great onwards ${ }^{14}$. We can see that the formal act of the census is interpreted in a spiritual sense: the census is Christianised and imbued with a sacred and redemptive meaning; nevertheless, the reference to the eternal life and the heavenly citizenry reveals the memory of the legal significance this act had in Roman law.

No relevant elements on this passage can be found in Eusebius of Caesarea ${ }^{15}$. However, Ambrose of Milan dwelt extensively upon it in his Exposition on the Gospel of Luke, written towards the end of the fourth century. Notwithstanding his reliance on Origen's reading, ${ }^{16}$ the originality of his

https://web.archive.org/web/20101207125246/http://www.chronicon.net/chroniconfiles/Hippolytus\%20Commentary\%2 0on\%20Daniel\%20by\%20TC\%20Schmidt.pdf >, accessed 2 May 2017).

${ }^{11}$ See e.g. Justin Martyr’s Dialog with Trypho (\$78.4) and Tertullian’s Against Marcion (IV, §§7.7, 19.10, 36.8-9); Clement of Alexandria's Stromata (I, 21, §145.1) mentions the census in his chronology of the world. I checked all the, mainly cursory, references to Luke 2:1-5 in texts from first to third century collected by the expanded Biblia patristica online at <http://www.biblindex.org > (accessed 2 May 2017).

${ }^{12}$ As is well known, the military metaphor is of Pauline origin, and had been widely used since the time of the early martyr acts; see the classic study by Adolf Harnack, Militia Christi: The Christian Religion and the Military in the First Three Centuries, ET by David Mclnnes Grade (Philadelphia, 1982), and, for a broader and recent overview, Katherine Allen Smith, War and the Making of Medieval Monastic Culture (Woodbridge, 2011), 71-111.

13 The text is: "in totius orbis professione describi oportuerit et Christum, ut cum omnibus scriptus sanctificaret omnes et [...] ut post hanc descriptionem describeret quoque ex orbe secum "in librum viventium", ut quicunque credidissent in eo, postea cum sanctis illius "scriberentur in caelis" (Origen, Homélies sur saint Luc, ed. Henri Crouzel, François Fournier and Pierre Perichon (Paris, 1998), Homélie XI, 196). The translation is in Homilies on Luke, ET by Joseph T. Lienhard (Washington, 2006), 47.

${ }^{14}$ Gregorius Magnus, Homiliae in evangelia, ed. Raymond Etaix (Turnhout, 1999), VII, II.4-6, 54: 'Quid est quod nascituro Domino mundus describitur, nisi hoc quod aperte monstratur, quia ille veniebat in carne, qui electos suos ascriberet in aeternitate? Quo contra de reprobis per Prophetam dicitur: deleantur de libro viventium, et cum justis non scribantur'. A similar interpretation, for instance, in Hugh of St. Cher (Hugonis cardinalis opera omnia in universum Vetus, et Novum Testamentum, 8 vols (Venezia, 1703), 8: fol. 143r), and Albert the Great (Enarrationes in primam partem Evangelii Lucae, in Opera omnia, ed. S. Borgnet (Paris, 1894-95), §2,1, 22: 190).

${ }^{15}$ Eusebius mentions the census when dealing with chronological aspects and the context of the nativity, e.g. in the Ecclesiastical history (I, §5, 2-6), or in the Questions on the Gospel (1,12). As for the surviving parts of his Commentary on Luke (a text which is corrupted and never quoted by other Church Fathers, see David S. WallaceHadrill, 'Eusebius of Caesarea's Commentary on Luke: Its Origin and Early History', HThR, 67(1974), 55-63) no significant elements are present.

${ }^{16}$ On the close connection between Ambrose and Origen's lectiones, see the Giovanni Coppa, 'Introduzione', in Ambrogio, Esposizione del Vangelo secondo Luca, ed. Giovanni Coppa, 2 vols (Roma, 1978), 1: 9-63, at 32-35, and 
contribution is undoubted. Equally undoubted is his influence: the Exposition is one of the main sources of both the Glossa ordinaria ${ }^{17}$ and of Thomas Aquinas' Catena aurea ${ }^{18}$ of these evangelical verses. Ambrose's experience as a iudex before becoming a bishop may well explain this originality: it is his juridical knowledge that makes him a key figure in any historical attempt to probe the constant interchange between theological and juridical conceptualisations in the Western tradition $^{19}$.

Ambrose evidently shifts the legal, earthly connotation of the census onto a spiritual plane, making it a 'spiritual census' ('professio spiritalis'). Indeed, he writes:

while the secular census is appointed, the spiritual is fulfilled, to be told, not to the king of the lands, but to the king of Heaven. The profession of faith is a census of minds; for when the old census of the synagogue was abolished, a new census of the Church was prepared which did not require torments, but abolished them, and spiritually through Christ conferred its names now on a figure of a people ${ }^{20}$.

Through the profession of faith, souls are registered, and the secular census - Roman or Jewish - is replaced with that of the religious community. This census is to be declared to the king of Heaven; neither material or social conditions must be accounted for, but the deepest corners of the mind: in this registration 'dimensions, not of lands, but of minds and spirits are assessed', because 'faith alone seals each'21.

This is a more universal census than that imposed by Augustus. Everybody, notwithstanding their nationality or their age, is involved:

Celestino Corsato, La Expositio Evangelii secundum Lucam di sant'Ambrogio: ermeneutica, simbologia, fonti (Roma, 1993), 183-91.

${ }^{17}$ The marginal gloss is ascribed to Augustine and Bede, but, as I show, Ambrose is the source, together with the Venerable; the gloss reads: 'In quo nomen augusti vere impletur qui suos augere sufficiens - censoribus suae professionis non pecuniae: sed fidei oblatione signare praecepit: quia dum professio secularis obstenditur, spiritalis impletur. Abolito autem censu synagogae vetusto novus census ecclesiae paratur, qui tormenta non exigit: sed aufert; qui non uno numismate: sed una signatur fide' (glo. 'Exiit edictum a ce. aug.', ad Lc 2, 1 in Biblia latina cum Glossa ordinaria, Facsimile Reprint of the Editio Princeps, Adolph Rusch of Strassburg 1480/81, ed. Margaret T. Gibson and Karlfried Froehlich (Turnhout, 1992)).

${ }^{18}$ See Thomas Aquinas, Catena aurea in quatuor evangelia, ed. Angelico Guarienti, 2 vols (Torino, 1953), 'In Lucam', §II.1, 2: 29-30.

${ }^{19}$ For a description of how Ambrose uses Roman law, both in his borrowing of terminology and in his theological reinterpretation of resolutions codified in the imperial leges, see Jean Gaudemet, 'Droit séculier et droit de l'église chez Ambroise', in Giuseppe Lazzati, ed., Ambrosius episcopus. Atti del Congresso internazionale di studi ambrosiani nel 16. centenario della elevazione di sant'Ambrogio alla cattedra episcopale, 2 vols (Milano, 1976), 1: 286-315, at 287300; see also Brunella Moroni, 'Lessico teologico per un destinatario imperiale. Terminologia giuridico-amministrativa e cerimoniale di corte nel De fide di Sant'Ambrogio', in Luigi F. Pizzolato and Marco Rizzi, ed., Nec timeo mori. Atti del Congresso internazionale di studi ambrosiani nel XVI centenario della morte di sant'Ambrogio (Milano, 1998), 341-63, at 343-5.

${ }^{20}$ Ambrose of Milan, Exposition of the Holy Gospel According to Saint Luke, ET by Theodosia Tomkinson (Etna California, 1998), §II.36, 50 (tr. slightly modified; Latin text according to the CChrSL critical edition in Ambrogio, Esposizione, 1: 176).

${ }^{21}$ Ambrose, Exposition, §II.36, 50; see also §II.38, 51. 
None is exempt from this census, because every age is liable to serve Christ [...]. Then, that ye may know that the census is not of Augustus, but of Christ, the whole world is bidden to enrol. When Christ is born, all confess Him; when the world is included, all are tested.

A census with such universal reach, concludes Ambrose, can be mandated only by a lord who has 'power (imperium) over the whole world' ${ }^{22}$. In his reading, the birth of Christ heralded the beginning of a movement towards a spiritualisation and universalisation, which led from the secular census to the spiritual one, and substituted the power of Augustus with that of Christ. The analogy between the king of Heaven (rex caeli) and the king of the lands (rex terrarum) recalls the one between what Augustine will call the two cities, although Ambrose does not make this explicit ${ }^{23}$; Augustine, however, does not comment on the universal census mentioned by Luke, neither in The City of God, nor elsewhere.

A first discussion of this analogy with regard to the verses in question - and, thus, a political interpretation of them, implicitly aimed at the justification of Roman authority - can be found in Orosius, who is key when discussing Church and Empire. In the History against Pagans, drawing on the synchronicity of Christ's birth and Augustus' peaceful reign, he develops a 'theology of Augustus' and associates the Christianisation of the figure of the emperor with the Romanisation of the figure of Christ: the unification of the orbis Romanum under Augustus is held to be part of God's plan for the propagation of the Gospel, and the emperor is presented as the forerunner of Christ, who, in turn, endorsed Rome as his fatherland, thus offering a justification of imperial power ${ }^{24}$. In arguing this, Orosius notes incidentally that Jesus's participation in the census had demonstrated that he wanted to be a Roman citizen:

to her [i.e. Rome], in preference to all others, He chose to belong when He came, thereby making it certain that He was entitled to be called a Roman citizen according to the declaration made in the Roman census list (dicendus civis Romanus census professione Romani). ${ }^{25}$

Let us now look at the other important source for the Glossa ordinaria on this passage, that is, at the Venerable Bede. In one of his homilies he interweaves all the elements analysed so far: he reads the pericope in a spiritual sense - as did Origen and Ambrose -, while also stressing its political and

\footnotetext{
${ }^{22}$ Thus ibid., §II.37, 50; in the Latin text (Ambrogio, Esposizione, 1: 178) : 'Denique, ut scias censum non Augusti esse, sed Christi, totus orbis profiteri iubetur. Quando nascitur Christus, omnes profitentur; quando mundus concluditur, omnes periclitantur. Qui ergo poterat professionem totius orbis exigere nisi qui totius habebat orbis imperium?'

${ }^{23}$ There are some mentions of Ambrose's distinction between the two orders - divine and civil - and of the superiority of the former, in Gaudemet, 'Droit séculier et droit de l'église', 304-6.

${ }^{24}$ Orosius also argues that 'Christi gratia praeparatum Caesaris imperium'. On the 'theology of Augustus' elaborated in book VI of the Historiae, see Erik Peterson, Der Monotheismus als politisches Problem. Ein Beitrag zur Geschichte der politischen Theologie im Imperium Romanum (Leipzig, 1935), and Opelt, 'Augustustheologie'. See also HansWerner Goetz, Die Geschichtstheologie des Orosius (Darmstadt, 1980), 71-88, and, for a recent, critical, reading of the Eusebianism of Orosius, Peter Van Nuffelen, Orosius and the Rethoric of History (Oxford, 2012), 191-97.
}

${ }^{25}$ See Paulus Orosius, Seven Books of History against Pagans, ET Irving W. Raymond (New York, 1936), §VI.22.8, 429; see also §VII.3.4. 
historical meaning, as did Orosius, making the analogy between the city of God and the city of men very explicit. According to Bede, the true fatherland is the Church, and, to an even greater extent, the heavenly Church. The census proclaimed by Augustus is to be carried out spiritually in obedience to the King of Heaven:

The fact that all were going, in response to the edict of Augustus, each to report to his own city, [betokens what] we must do spiritually (spiritaliter) as a service to our king. Indeed, our city is the holy church, which is in part still journeying away from the Lord on earth, and in part already reigns with the Lord in heaven.

The tax ('debitum censum') which 'is due to the king who has been born' attests a spiritual debt which has to be paid by complying 'with divine commands in the unity of the Church now present' and 'by the tireless course of good works ${ }^{26}$. Bede adds that we ought to represent Christ's image 'on the same denarius of our good way of life (bonae nostrae conversationis)': and as in the case of the coin of Augustus, the currency of payment is legal tender when stamped with the head of the ruler, that is, if the way of life is hallmarked by the image and name of Christ, and obedience to his commands ${ }^{27}$.

Bede's exegesis makes clear the extent to which the heavenly kingdom is based on an economy of salvation: moral conduct becomes the currency, and is exchanged in the circulation of credit and debt which began with the coming of the redeemer, who gave himself for human sins. Here we touch upon a further confirmation of the widespread use made by the Christian sources of a preexistent economic and legal lexicon, but also, conversely, of the decisive contribution made by these sources to the evolution of such a lexicon ${ }^{28}$.

All this on the spiritual exegesis and the spiritual debt which has to be paid in the spiritual realm by Christians through their moral actions. At the same time, focussing on the historical, literal, sense of the biblical text, Bede highlights that there is a secular debt to be paid on earth, to the Empire. Jesus

\footnotetext{
${ }^{26}$ Bede the Venerable, Homilies on the Gospel. Book One: Advent to Lent, ed. David Hurst (Kalamazoo - Michigan, 1991), §I.6, 54; Latin text in Beda venerabilis, 'Homiliarum Evangelii libri II', in Bedae Opera. Pars III/IV Opera Homiletica, ed. David Hurst (Turnhout, 1955), §I.6, 37-45, at 38. See also Beda, 'In Lucae evangelium expositio', in Bedae Opera. Pars II.3 Opera exegetica, ed. David Hurst (Turnhout, 1960), §II.1-5, 46: 'Imperante Augusto et Cyrino praesidente ibant omnes ut censum profiterentur singuli in suam civitatem ita et nunc imperante per Ecclesiae praesides, id est doctores, imo suadente et praemia pollicente Christo, eamus omnes, nullus excipiatur a censo iustitiae'.

${ }^{27}$ Bede, Homilies, §I.6, 54; Latin text as follows: 'Dabatur autem in professione census denarius qui decem nummorum in se pondus habebat Caesaris imaginem continens et nomen. Quod nos quoque spiritaliter oportet imitari; solvimus enim regi nostro denarium cum decem praecepta legis illius implere satagimus in quo videlicet denario nomen eiusdem nostri regis conscriptum gestamus cum in cunctis actibus nostris meminerimus nos a Christo christianos vocari ac dignitatem nominis ipsius intemeratam in nobis conservare curamus. Imaginem quoque eius in eodem denario bonae nostrae conversationis exprimere debemus illam utique quam ipse docuit dicens: "Sancti estote quia et ego sanctus sum dominus Deus vester”' (Beda, 'Homeliarum Evangelii', §I.6, 38-39)

${ }^{28}$ As a number of studies have highlighted, an economy of salvation is defined within Christendom, which requires appropriate behaviour and includes, far more than a censure of wealth, a meditated administration of material exchange. See Giovanni Todeschini, Il prezzo della salvezza. Lessici medievali del pensiero economico (Roma, 1994), Valentina Toneatto, Les Banquiers du Seigneur (Rennes, 2012), and Paolo Evangelisti, Il pensiero economico nel Medioevo (Roma, 2016).
} 
himself, in undergoing the earthly census, confirmed its legitimacy, thus stating the need for believers to be subject to the authority of all earthly, political, institutions ${ }^{29}$ :

He himself did not disdain to commit himself to servitude to one who was unaware of true charity. Here also by his example he pointed out in advance what the prince of the apostles was afterwards to teach in words, "Be subject to every human creature for God's sake, whether to the king as sovereign, or to the leaders as sent by him (1Pet 2:13-14)".

\section{Some thirteenth- and fourteenth-century interpretations: exegesis and beyond}

Bede introduces a direct connection with the theme of obedience to established temporal power, which was hinted at by Orosius and frequently recurs in subsequent exegeses on these verses from Luke's Gospel. Nothing significant has been found in any Carolingian commentaries on Luke's Gospel, but the theme then appears to have been much developed in the thirteenth and fourteenth centuries, during which commentaries on the Gospel proliferated ${ }^{30}$. While a complete survey of these fallsoutside my remit, I will now touch on a few, representative examples of the political reading of the pericope in medieval exegetical, political and juridical texts.

In the thirteenth century, Hugh of St. Cher defines the census as 'the exhibition of subjection (subiectionis exhibitio)', while Albert the Great, in addition to drawing the usual analogy between the descriptio orbis and the descriptio in aeternitate, refers to Matt 22:21 and his well-known exhortation to render 'to Caesar the things that are Caesar's'31. Bonaventure of Bagnoregio should finally be mentioned for his very explicit remarks on this question. In his Commentary on the Gospel of $L u k e^{32}$, he directly quotes Bede, and emphasises the fact that Jesus was enrolled in order to comply with all higher authorities, making it clear that 'human authority is similar to divine' and 'the command of rulers is not to be contemned in any way' ${ }^{33}$. The power of Augustus, mandating a

\footnotetext{
${ }^{29}$ Bede, Homilies, §I.6, 57; Beda, 'Homiliarum Evangelii, §I.6, 40: 'Ubi hoc quoque suo praemonstravit exemplo quod postmodum apostolorum principis erat verbo docturus: "Subditi”, inquit, "estote omni humanae creaturae propter Deum sive regi quasi praecellenti sive ducibus tamquam ab eo missis” (1Pet 2:13-14)'.

${ }^{30}$ As for the Carolingian era, I checked Christianus Druthmarus Stabulensis, Expositio In Lucam Evangelistam, in PL 106, 1503-1514; Walafridus Strabo Fuldensis, Expositio In Quatuor Evangelia. In Lucam, in PL 114, 893-904; Sedulius Scotus, In argumentum secundum Lucam expositiuncula, in PL 103, 285-90. A list of medieval commentaries on Luke's Gospel is given by Faes de Mottoni, 'Introduzione', in Sancti Bonaventurae Commentarius, 1: 7-26, at 1920 , which includes more than 20 commentaries in the thirteenth century.

${ }^{31}$ Hugonis cardinalis opera omnia, 8: fol. 139v, and Albertus Magnus, Enarrationes, §2,1, 22: 190. See Alberto Colli, 'Considerazioni sul censimento di Cesare Augusto nelle esegesi di Ugo di St. Cher e Alberto il Grande', Politica e religione. Censo, ceto, professione, (2015), 121-40.

${ }^{32}$ Bonaventure, Works, 8/1: St. Bonaventure's Commentary on the Gospel of Luke: Ch. 1-8, ed. Robert J. Karris (New York, 2001); the Latin text is in Sancti Bonaventurae Commentarius in Evangelium S. Lucae, ed. Barbara Faes de Mottoni, 4 vols (Roma, 1999-).

${ }^{33}$ St. Bonaventure's Commentary, $\S 8,143$ (Bede is quoted in $\S 4,138$ ).
} 
universal census in a time of universal peace, prefigures the authority of Christ, but, at the same time, retains its temporal significance. In registering themselves, indeed, Joseph and Mary

did the will of the king, and no one did otherwise. And thus they made themselves subject to the king in registering (subiectionem habebant ad regem in professione), in acknowledgment of his authority and made peace with one another through tranquil and just living together, according to what Romans 13:7-8 has; "Render to all whatever is their due. Tribute to whom tribute is due"[...] To register that they are subject to Roman rule, and this by undergoing the census. And this was just, as Matthew 22:21 has: "Render to Caesar the things that are Caesar's, and to God the things that are God's". [...] Through her obedience she [Mary] would give us an example of how to obey all higher authority, in accordance to what we read in 1 Peter 2:13$14^{34}$.

The link between census and subjection could not be more explicit, and is stressed by the recalling of a number of biblical passages typically quoted by Christian authors in regard to political subjection (Matt 22:21, Rom 13:7-8, 1Pet 2:13-14) ${ }^{35}$. One cannot help but think of the canon collected in the Liber Extra (X 3.39.2) which, echoing Augustine, clearly defines the praestatio tributi as probatio subiectionis ${ }^{36}$. The census signals subjection to a king, whether earthly or celestial: it is an act of inclusion - political and/or theological - which signals admission into an established, peaceful order, but is also a necessary act of salvation.

This observation does not apply only to Christian exegetical scholarship. It is intriguing to note that Dante Alighieri, in his De monarchia, refers to Jesus's compliance with the imperial edict on the census to legitimise the jurisdiction of the Roman Empire - and, consequently, the legitimacy and the independence of temporal power in general ${ }^{37}$. Some jurists referred to Luke's narrative when prescribing the fulfilment of political, and in particular fiscal, obligations: in the thirteenth century Rolandus de Luca, for example, repeatedly mentions this narrative when commenting on the issue of taxation ${ }^{38}$. Luke's pericope was also evoked when declaring the legitimacy and supremacy of the Emperor's authority over local kings and princes, for instance in Bartolus of Saxoferrato's

\footnotetext{
${ }^{34}$ Ibid., §5, pp. 139-40 (translation slightly modified; Latin text in Sancti Bonaventurae Commentarius, §5, 1: 168).

${ }^{35}$ On the exegeses of these passages, in the framework of a discussion of the Christian thought on political subjection, see Marco Rizzi, Cesare e Dio. Potere secolare e potere spirituale in Occidente (Bologna, 2009), which, however, never mentions Luke 2:1-5.
}

${ }^{36}$ See Peter Landau, 'Die Verteilung kirchlicher Abgaben in klassischen kanonischen Recht', in Franck Roumy, Mathias Schmoeckel, Orazio Condorelli and David von Mayenburg, ed., Der Einfluss der Kanonistik auf die europäische Rechtskultur. Das Recht der Wirtschaft (Köln, 2016), 223-42.

${ }^{37}$ See Dante Alighieri, De monarchia, in Opere, ed. Marco Santagata (Milano, 2014), §II.10.6 and 8, 2: 1200-02: 'Cristus [...] sub edicto romane auctoritatis nasci voluit de Virgine Matre, ut in illa singulari generis humani descriptione filius Dei, homo factus, homo conscriberetur: quod fuit illud prosequi. [...] Cristus Augusti, Romanorum auctoritate fungentis, edictum fore iustum opere persuasit. Et cum ad iuste edicere iurisdictio sequatur, necesse est ut qui iustum edictum persuasit iurisdictionem etiam persuaserit'.

${ }^{38}$ See Sara Menzinger, Verso la costruzione di un diritto pubblico cittadino, in Emanuele Conte, Sara Menzinger, ed., La Summa Trium Librorum di Rolando da Lucca (1195-1234). Fisco, politica, scientia iuris, CXXV-CCXVIII, at CLVI. 
commentary on the Digesta (written in the first half of the fourteenth century) ${ }^{39}$ and Bartolomeus of Novara's commentary on the Institutiones (published, later in the same century, under the betterknown name of Baldus de Ubaldi) ${ }^{40}$. The comment by Bartolus, perhaps the most important Italian jurist of his time, is striking for its explicit claim (grounded on our periscope) that Christian doctrine demands the recognition of the Emperor's authority. He deals at length with the lex 'Hostes' (D. 49.15.24) and, in defining the concept of enemy and Empire, notes indeed:

And if someone argues that the emperor is not the lord (dominus) and the king of all the world, they are heretics, as they speak against the decisions of the Church, against the holy Gospel which says: "a decree went out from Emperor Augustus that all the world should be registered" [...] In this way, even Christ acknowledged the emperor as lord ${ }^{41}$.

\section{Conclusion}

According to the exegetical tradition I have just outlined, the Roman juridical institution of the professio census became a theoretical tool for Christian theologians to use in their conceptualising of the economy of salvation: it was used to describe someone's admission to the eternal life, foreshadowing the last judgement, and to explain why each Christian is indebted to Christ, and the way in which this debt must be paid. A spiritualisation of this institution occurred, showing that the spiritual empire of Christ had replaced the temporal empire of Augustus. This juridical institution also allowed theologians to acknowledge the authority of Roman emperors, and to justify the Christian acceptance of, and subjection to, political authority. Luke's pericope should, indeed, find its place alongside other, well-known, biblical references used to this purpose as Matt 22:21, Rom 13:7-8, 1Pet 2:13-14; this observation is confirmed by the use that Dante Alighieri and some medieval jurists made of the pericope. Starting from the law and ending with it, my analysis has hopefully highlighted some reasons why the census is a perfect example of the close overlap between theological and juridical concepts and practices which is a key feature of the relationship between the Church and Empire in European tradition.

\footnotetext{
${ }^{39}$ Bartolus a Saxoferrato, Super Digesto Novo (Basilea 1563). On the use of theological sources made by Bartolus, see Diego Quaglioni, 'Diritto e teologia nel «Tractatus testimoniorum» bartoliano', in Idem, "Civilis sapientia”. Dottrine giuridiche e dottrine politiche fra Medioevo e Età moderna (Rimini, 1989), 107-25. The important, anonymous treatise Questiones de iuris subtilitatibus, written in the twelfth century, had already mentioned the census ordered by Augustus in arguing a similar thesis; see Magnus Ryan, 'Political thought', in The Cambridge Companion to Roman Law, ed. David Johnston (Cambridge, 2015), 423-51, at 428-29.

${ }^{40}$ Baldus de Ubaldis, Commentaria ad quatuor Institutionum libros (Lyon, 1585), ad I.1.12.5, fol. 10v. The text was indeed probably quite well known as it was printed at the beginning of the modern era under the name of Baldus, who was Bartolus's pupil and an important scholar in his time. On the true identity of the author of this commentary, see Domenico Maffei, 'Bartolomeo da Novara autore della Lectura Institutionum attribuita a Baldo degli Ubaldi?', Rivista di storia del diritto italiano 63(1990), 5-22).

${ }^{41}$ Bartolus a Saxoferrato, Super Digesto Novo, ad D. 49.15.24, my ET.
} 